\title{
Challenges of criminalization protest and corruption by looking at international documents
}

Desafíos de la criminalización de la protesta y la corrupción a través de documentos internacionales

Mina Torabi*

Islamic Azad University - Iran minatorabi1349@gmail.com Mohammad Javad Jafari**

Islamic Azad University - Iran dr.jafari14@gmail.com Masood Ghasemi***

Islamic Azad University - Iran md.ghasemi63@gmail.com

\begin{abstract}
With the passage of the Islamic Penal Code of 1992, the legislator took a critical step contrary to the provisions of international documents such as the Political and Civil Covenant and the Universal Declaration of Human rights and other documents criminalize behaviors that are critical of human rights, both in terms of punishment and in non-compliance with the principles and principles of criminality. As provided in Article 286 for severe on-the-ground corruption with a view to development in various fields, the death penalty has been specified. The perpetrators of these crimes and deviations from the substantive principles of security crimes, such as riots and corruption on earth, present challenges that will be addressed in this article, first explaining the importance of the right to life and the death penalty in international documents and the Iranian legal system.
\end{abstract}

Keywords: Principles, Human Rights, On-Earth Corruption, rebellious

\section{RESUMEN}

Con la aprobación del Código Penal Islámico de 1992, el legislador dio un paso crítico contrario a las disposiciones de Los documentos internacionales como el Pacto Político y Civil y la Declaración Universal de Derechos Humanos y otros documentos penalizan comportamientos que son críticos de los derechos humanos, tanto en términos de castigo como en incumplimiento de los principios y principios de criminalidad. Según lo dispuesto en el Artículo 286 para la corrupción severa en el terreno con miras al desarrollo en varios campos, se ha especificado la pena de muerte. Los autores de estos crímenes y las desviaciones de los principios sustantivos de los crímenes de seguridad, como los disturbios y la corrupción en la tierra, presentan desafíos que se abordarán en este artículo, primero explicando la importancia del derecho a la vida y la pena de muerte en documentos internacionales y el sistema legal iraní.

Palabras clave: Principios, Derechos Humanos, Corrupción en la Tierra, rebelde.

\footnotetext{
${ }^{*}$ Department of Law, Kermanshah Science and research branch, Islamic Azad University, Kermanshah, Iran. **Department of Law, Kermanshah Science and research branch, Islamic Azad University, Kermanshah, Iran.

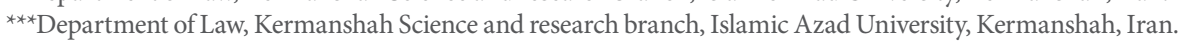

Recibido: 03/05/2019 Aceptado: 18/08/2019 


\section{Introduction}

A review of international human rights instruments shows that international human rights instruments tend to abolish the death penalty from the list of countries' penal systems. A review of Article 6 of the Covenant on Civil and Political Rights is well-represented, and the wording of these documents is set out as if the death penalty were an unpopular punishment that should be abolished from the scene of human life. Punishment should not be used in any way for crimes relating to property, economic and political crimes, and in general, crimes which do not involve coercion or coercion. Essentials such as the principle of legality of offenses and penalties, the principle of proportionality of penalties, profits and non-exchange or Lawlessness, transparency, and comprehensiveness of the law are also essential in criminalizing the formal principles that the most prominent of these principles are the public and fair trial in a competent court, the presumption of innocence, the trial of reasonable time, the trial without unnecessary delay, the presence of the court, and personal defense by an elected lawyer. See Articles 286 and 287 of the Islamic Penal Code of 2013 for criminalization and prosecution of rape and corruption offenses. Many of these principles have not been adhered.

in this article, first, while discussing the importance of the right to life, we address the objections and criticisms that exist in the field of human rights in imposing the death penalty for extrajudicial and extrajudicial crimes, and then addressing the most important and substantive modalities to be observed in International documents are needed, but we have not been involved in the criminalization and investigation of these crimes.

1. The importance of the right to life and the death penalty in international documents and the Iranian legal system

The right to life and its prohibition is recognized in Islam and in international human rights instruments. One of the most important issues of the Universal Declaration of Human Rights is the right to life and protection of human life and health. Therefore, in order to protect human life, international instruments are geared towards abolishing the death penalty from the list of countries' penal systems. In this article, we review international documents and regulations in this regard.

\section{A. The Covenant on Civil and Political Rights}

The right to life is one of the most fundamental human rights; the other right enshrined in international human rights instruments is the right to life. The importance of this right is such that it cannot be violated even in an emergency. As stated in Article 4 of the Sassi Civil Covenant Law: "The right to life is an inherent human right. This right shall be protected by law and no one shall be deprived of his life without authorization. Article 6 of the Covenant on Civil and Political Rights stipulates that in countries where the death penalty has not been abolished, the sentence shall not be limited to the most serious and serious offenses under the law in force at the time of the commission of the crime, nor shall it be prohibited by the provisions of the present Covenant and the Convention. The punishment for the crime of mass murder is inconsistent.

\section{B. The Universal Declaration of Human Rights}

Article I of the Universal Declaration of Human Rights states:

1. Life is a gift from God and the right to life is guaranteed to all human beings. All populations, governments, and individuals are obliged to protect and defend the right to life against any abuse and to interfere with any natural disruption such as diseases and human disasters, and it is not permissible to sever any part of the body without the right to worship.

2. It is forbidden to use any means to destroy the fountain of human life, both wholly and in part.

3- Preserving human life as long as God wants it to, whether it be protecting one's life from the oppression of others or abusing oneself.

And Article 3 of the Declaration states "Everyone has the right to life, liberty and security of person.”

Article 5 of the Universal Declaration of Human Rights states: "No one shall be subjected to torture or to any form of torture or to cruel, inhuman or degrading treatment or punishment."

Article 13 Residence: Everyone has the right to the protection of the law against arbitrary interference with his privacy, family, home or correspondence."

The Declaration does not explicitly mention the death penalty, but Article 3 protects the right to life. Article 5 also prohibits cruel, cruel and inhumane punishment. If we consider the death penalty subject to torture and cruel punishments, then we can conclude that the declaration was intended to abolish the death penalty. (Although the minority's opinion that they wanted the death penalty to be announced was not met with everyone's consent and did not refer to the punishment in the final text.

\section{C: The International Criminal Court}

Article 5 of the Criminal Court is within the jurisdiction of the Tribunal. (A) The crimes of genocide; (b) The crimes against humanity; (c) The crimes of war (d) The crimes of rape. 
Article 77 lists the penalties applicable. 1. Subject to Article 10 of the Statute, the Tribunal may impose one of the following penalties on a person convicted of an offense set forth in Article 5.

(A) Imprisonment to a certain extent not exceeding thirty years; - Life imprisonment provided that the importance of the offense commits, as well as that of the offender and the circumstances of the offender.

Paragraph 2 - The Court may order, in addition to detention, that: (a) The penalties shall be in accordance with the criteria set forth in the Rules of Procedure and Evidence of the Court; (b) the proceeds of property or property derived directly or indirectly from the commission of the offense; May be recorded without prejudice to the rights of any third party in good faith.

Subject to the conditions which any State may determine in accordance with paragraph (b) of Article 103, States Parties shall be bound by the sentence of imprisonment and may in no case change it. The only authority that cannot rule on an appeal against the decision of the court or a judgment of conviction or punishment of the court is the court itself.

It is noted that the International Criminal Court has abolished the death penalty in general

D: The death penalty in regional documents and treaties

The principle of the European Convention on Human Rights is based on respect for the private life of individuals and the punishments. Article 3 The European Convention on Human Rights refers to the right to life and prohibits deliberate cessation of service. Article 3 prohibits torture and inhuman or degrading treatment or punishment in all its member States. The right to life in the Treaties is not absolute and subject to conditions. However, Article 15 of the Convention cannot be violated in times of war or when a nation's life is in danger. But other restrictions are likely to be contained in Article 15 (2) itself (death due to legitimate acts of war). The statute of limitations explicitly reserved the right of States to enforce the death penalty issued by a court in the case of a crime legally entitled to such punishment. Except as otherwise provided in the Convention, the intentional death of a person is contrary to the provisions of the Convention; accordingly, international human rights instruments seek to abolish the death penalty from the list of penalties of countries.

The review of Article 6 of the Covenant on Civil and Political Rights illustrates this fact well. The wording of these documents is set up as if it were an unpleasant punishment that should be abolished from the scene of human life. Additional protocols to these documents have been drawn up to abolish the death penalty, Confirms this claim. The second Peruvian Protocol to the Covenant on Civil and Political Rights, the Second Protocol to Civil Rights - for the Abolition of the Death Penalty, is the sixth protocol to the European Convention on Human Rights concerning the abolition of the death penalty. The 1990 Protocol to the American Convention on Human Rights are international documents aimed at abolishing the death penalty for Ted Vienna.

It should be noted that according to the Human Rights Committee's interpretation, this punishment should not be used in any way in relation to property, economic and political crimes, or crimes that do not involve coercion.

E: life imprisonment penalty in Iranian legal system

Some of the most important crimes punishable by death under Iranian law include:

Murder for adultery, relative adultery, adultery with father, non-Muslim adultery with Muslim woman, adulterer, rape and reluctant adulterer.

Sodomy

Moharebeh and on the ground

Rebellion

Killed for adultery for the fourth time after being thrown three times

Interrogation for the fourth time after thrashing three times

Drinking water for the third time after exceedingly twice the limit

Execution for robbery for the fourth time after three times the limit

Execution for adultery

Death penalty for offenders who are subject to the death penalty under the Narcotics Act if they meet one of the most serious conditions of corruption on earth: a) cases where a criminal or at least one of the partners has committed a weapon while committing a crime; With intent to deal with agents, firearms or predators b) if he or she has the role of abuser, financial backer, or transition agent, or of children or adolescents under the age of 18, or manslaughter, To use. (C) If he or she commits a crime, subject to the law, has a definitive sentence of death or imprisonment of more than fifteen years for all the offenses committed. Substances referred to in Article 8 shall be deemed to be more than $2 \mathrm{~kg}$.

Punishment of retribution for premeditated murder

Notwithstanding the international orientation towards the abolition of the death penalty from the list of penalties of countries, it is noted that our country anticipates the punishment in the above cases and the addition of the 
death penalty for offenders and corruption on earth to the list of criminal offenses. It has applied international pressure and has drawn international criticism in this respect, which is worthy of reviewing the rules and considering the principles of criminalization of such jurisprudent crimes as well as observing the principle of proportionality and the principle of law. Being offenders and other principles for committing these cholera behaviors In view of the risks to security and a more appropriate penalty to be determined.

\section{Challenge in human rights criminalization of perpetrators and corruption}

By examining the provisions of international instruments such as the Universal Declaration of Human Rights, the Covenant on Civil and Political Rights, and the International Covenant on Economic and Legal Rights, and with regard to Iran's accession to the Covenants, some of the principles and arrangements sought by international legislators in Baghdadi's criminality and corruption on earth have not been respected, and this has led to criticisms of human rights over the imposition of the death penalty for these crimes. Among the most important principles that are essential to criminalizing conduct in accordance with international documents are the principle of legality and necessity of punishment, the principle of reasonable time, and the use of defense counsel in all stages of Darcy's challenge. In the above-mentioned principles, we focus on rebellious criminality and corruption on earth.

A. The principle of legality of crime and punishment

Article 29 of the Universal Declaration of Human Rights states that "Everyone has the right to freedom of expression only subject to the restrictions provided for by law and solely for the purpose of providing for, recognizing and observing the rights and freedoms of others for the purposes of morality and the common law and order. The conditions of democratic society have been established.

Article 4 of the International Covenant on Economic, Social and Cultural Rights also provides “... in respect of the rights provided for in the present Covenant in any State. A State may not subject such rights to any restrictions other than those provided by law. And only to the extent that it was constitutional in nature and ... " The Article 12 of the Political Covenant on Civil Rights states that restrictions on the right of movement of persons are not permitted. "Except as Restricted by Law ..." Articles 19, 21,22 and Articles 2, 8, 9 and 10 of the Convention on the Principle of Legality with Interpretations such as "Determined by the Question of Law, as Provided by Law, The law, by law, is referred to by law and in accordance with the law

According to international law, the law must be of the required quality, meaning that it must be formally published and its content clear and unambiguous and made in a manner that is predictable to anyone. Also, in this law, the details and conditions of any restrictions on public rights and freedoms must be fully stated so that individuals can know their territory and limits. In addition, the law must be transparent and, thus, prevent tyranny in legislation.

Now, considering these three features, it can be said that Article 286 of the Islamic Penal Code of 2013 does not have all the above-mentioned characteristics. This article does not have the necessary transparency because it uses vague and widespread rhetoric. Extreme difficulty makes it difficult for the defendant and the judge to identify, meaning that it is not clear to the defendant whether the act committed by the defendant may be subject to extensive, extensive, or severe restraint. The vocabulary used in the context of the material is generalizable and interpretable, for example, one of the conditions necessary for the realization of corruption on earth is the widespread use of matter.

In the criminalization of rebellion, Article 287 of the Islamic Penal Code does not mention the number of rebel groups, and there is no clear and transparent legislative position. This article refers to the group, despite its stipulation (Article 186 of the Act). The former Islamic punishment, approved in 1991, for armed uprising (as stated) appears to be regarded by the legislator in Article 287 of armed uprising as a systematic activity, because if it had not been, there was reason to refer to the group. There was no mention of the person in the matter. But the minimum number of groups is not clear.

Another ambiguity in the article is that the armed uprising does not mean entering the armed phase, but it is necessary in practice to seize weapons against the very basis of the state. In addition, the expression used in Article 287 indicates that those who They are considered to be gardens that themselves have actually taken up arms. But the vague point is that the article states that if a weapon is used, but not told by a person or group, Dr. Mir Mohammad Sadeghi said in the book Crime Against Security: "If only armed rebellion by the group would have been a rebellion All members and supporters (which was the position of Article 186 of the Islamic Penal Code of 1991), in other words, if the term refers to the use of a non-individual group of weapons if the weapon is used, then The armed uprising against the basis of the Islamic Republic of Iran's government has indicated that there was no longer any need for "if used weapons" in the article."

Therefore, it can be said that Article 287 has brought two separate offenses. One is that the group has used a weapon against the basis of the system, and the other that a particular defendant has used a weapon. Note that if groups use weapons, not groups.

Therefore, the legislature has taken steps to address these issues without regard to the principle of transparency and quality that has been emphasized in international documents such as the Political Covenant on Civil Rights and the Universal Declaration of Human Rights, and has thus provided the basis for human rights criticism, It is 
therefore necessary for the legislator to adequately amend the aforementioned regulations so that the judicial system of the country will not be ambiguous in enforcing the law and that the minimum will not be deviated from fair and equitable principles.

\section{B: The principle of necessity}

In international human rights instruments, the principle or principle of the necessity to impose restrictions on the rights and freedoms of individuals and, in the first place, the necessity of applying these restrictions through criminality, the necessity of intervening in human rights instruments has come to pass. Articles 21, 22, 23 of the Covenant on Civil Rights, Articles 4 and 8 of the Covenant on Economic, Social and Cultural Rights Articles 6, 8, 9, 10 and 11 of the European Convention and Articles 15, 16 and 22 of the American Convention on Human Rights.

Despite Iran's adherence to the Covenant on Civil and Political Rights, and Economic, Social and Cultural Rights, but with some investigations into crimes against security, it is observed that, despite the essentiality of criminality, severe penalties have been imposed for some crimes. For example, in some of the provisions on rebellious criminality and on-earth corruption, severe punishments were not required in some cases to be met with lighter penalties, but severe penalties such as the death penalty or imprisonment were possible. It's been a long time. In this section we refer to the above.

\section{Stimulate and unseen in subversion}

Iran's Law before the Revolution, Article 14 of the Press Law passed in 1334, incited and encouraged people to commit a crime or crime that pointed to the country's internal or external security and provided for a specific criminal policy. Article 15 of the Act criminalized the commendation and praise of conduct contrary to the security of the State. Given that these two articles included any encouragement (before committing the crime) or praise (after committing the crime).

After the Islamic Revolution and in the Press Law of 1364, the limits of the press have been determined to determine and rank the material that is harmful to the Islamic Republic (Article 6) and to explicitly incite people to commit crimes or crimes against the security or foreign policy of the country, if any. It shall be punishable by a vice punishment of the same offense and, in the absence of any effect on it, by an independent penalty (Article 25). M. Effective instigation of combat forces or persons serving in the armed forces refers to rebellion, fleeing, or failure to perform military duties to overthrow the government or defeat its own forces.

In this article, intent to overthrow - albeit with no effect, that is, the armed forces do not respond to the instigations of the individual - results in the offense of Moharebeh (Article 287 of the Islamic Penal Code for such activities as new offenses). Has been criminally charged and returned to pretrial detention as a result of preliminary injunctions, but given the fact that the sentence is a death sentence and has been imposed on the moharebeh for four offenses and has the power to impose a sentence on the judge.

Interpretation in favor of the defendant demands that the same sentence be served on moharebeh), But if there is no intention of overthrow, if sentenced to work, imprisonment from 2 to 10 years and if not effective, punishment is lighter.

The legislator has also stipulated in Article 498: "Everyone shall, by any name, title, or office in any overseas overseas establishment under any name, title, or office with the purpose of undermining the security of the country, by any creed, class or population. And, if convicted, Mohareb is sentenced to two to ten years in prison.

Article 499 of the said law refers to membership in groups or populations or quasi-populations of the said article and for which a punishment of imprisonment is provided. Article 500 of the aforementioned law also criminalizes any kind of propaganda against the Islamic Republic in favor of organizations and groups opposed to the system.

\section{Conspiracy to commit a crime solely by agreement}

Article 610 of the Islamic Penal Code (Ta'zir) of 75 concerning offenses against security provides: "Whenever two or more persons gather or collude to commit crimes against domestic or overseas security or provide the means to commit it, "They are sentenced to two to five years in prison if they are not held liable for war crimes."

Article 611 has stated about other offenses (whenever two or more persons come together to take action against the public or the population or property of the people and have the necessary administrative arrangements but fail to do so without a will of six months to They will be sentenced to three years. "

With reference to Articles 610 and 611 of the Penal Code of 75, it is clear that the commission of a crime under Article 611 (conspiracy to commit other offenses) is subject to the existence of two other conditions in addition to obtaining an agreement to commit a crime between two or more persons. First of all, the contractors must "have the necessary administrative arrangements" and have failed to act without their will, while neither of the two conditions mentioned is necessary for the fulfillment of Article 610 collusion but merely for an agreement on security-related 
offenses. Domestic and foreign crimes are punishable and punishable under Article 610.

\section{C: Inappropriate punishment}

In the legal systems of many countries today, the right not to be subjected to inappropriate punishment is one of the fundamental principles of Wendy's law in the criminal law domain, a right that derives directly from human dignity. Many international, regional and national human rights instruments have been identified. At the international and regional level, Article 5 of the Universal Declaration of Human Rights (1948), Article 7 of the Convention on Civil and Political Rights (1966), Articles 2 and 4 of the Convention against Torture and Other Cruel, Inhuman or Brutal Punishment (1984), Article 5 of the Convention American Human Rights (1969) Article 3 of the European Convention on Human Rights (1950), Article 5 African Charter of Human Rights (1981) Article 49 of the European Union Charter of Fundamental Rights (2000) explicitly or implicitly prohibits the principle of proportionality between the offenses and the punishment of improper punishment. Emphasis added. The prediction of such provisions in the international human rights system actually indicates that today the period of absolute criminal and monopoly rule has ended in criminalization, punishment, prosecution and punishment of citizens.

The main cause of inappropriate punishments in the international human rights system as well as in domestic legal systems is the prohibition of the use of a human tool by respect for his or her inherent dignity. In the Iranian legal system, the principle of prohibiting inappropriate punishment is not provided for in any of the laws and regulations. The penalties provided in many criminal laws do not conform to the basic criteria of proportionality.

The right not to be exposed to inappropriate punishment is one of the most important ways in which this type of criminal justice can continue to exist. This right is therefore protected at international and regional level, such as Article 5 of the Universal Declaration of Human Rights and Article 7 of the International Covenant on Civil and Political Rights and Article 3 of the European Convention on Human Rights. It should be noted, therefore, that the criteria for proportionate punishment as a pillar of punishment in the criminal justice system are based on a relationship between crime and punishment, each based on the type and extent of the harm, the nature of the offense and the personal characteristics of the offender and the victim's guilt. Is. In this way, the prohibition of inappropriate punishment can be combined with both positive and negative approaches. On the one hand, the criminal justice system does not impose disproportionate penalties (on the other hand) and penalties on the other hand for those cases which are exceptionally in certain circumstances (involving a criminal or a victim or a criminal) by means of means. Fit to fit.

Criticism of Article 610 of the Islamic Penal Code for imposing inappropriate punishment is that the minimum punishment provided for by the law for the offense of collusion for a crime against security (which includes prosecution and corruption on earth) is the minimum legal punishment for Many crimes against security are greater. Such an approach cannot be defended from the point of view of the principle of proportionality of crime and criminal justice, and it indicates to what extent the legislator seeks criminal and enforced prevention of crimes against security ultimately establishing a public order and guaranteeing sovereign rights.

It is also one of the criticisms of Article 286 regarding corruption on earth that is why the article is set to include false broadcasting on a television program that has millions of programs. One jurist writes: "In the light of the recent provisions of Article 698 of the Islamic Penal Code and the principle of the legality of the crime, the scope of the article cannot be substantiated verbally, citing its irrationality, "Because logic is not something that can be invoked in the abolition of this principle and so the relevant institutions must take action to amend it by amending the law."

. In the on-the-ground corruption debate, the legislator has imposed the most severe punishment, namely execution, for acts that are not too severe. For example, even a deputy in a corruption case under Article 286 is subject to the death penalty. This punishment is disproportionate to the punishment of other crimes for aiding and abetting a criminal offense.

Article 287 of the Islamic Penal Code provides for the death penalty legislator, while such punishment in Islamic law is referred to as "murder of the rebel" or "jihad against the rebels", which differs from trial and conviction. And especially if those who have taken up arms with their religious coordinates as weapons.

Therefore, the imposition of penalties without regard to their proportionality is contrary to the requirements of the international instruments referred to. And Iran has adhered to some of these international laws, such as the Covenant. The prosecution and execution of some of the inappropriate punishments in Iran has always been objected to by organizations and in particular by human rights organizations, and by international problems. WikiLeaks is one of the penalties for a wide range of charges against Iran, while the international community is seeking to have the death penalty removed from the list of legal penalties or to reduce its application.

Principal 3: The publicity of the proceedings

The publicity of criminal proceedings has been an important feature of the prosecution system; the mixed system has tried to address this issue at the trial and criminal trials, although the preliminary investigation phase is being conducted in secret. The publicity of the trial is an important sign of fair trial, meaning that public opinion is on trial today. One of the challenges today is to extend the sovereignty of governments to expand public oversight of the city, 
ensuring the safety of government officials or government officials. The principle of openness of trials as one of the criteria for observing human rights in criminal proceedings is one of the most important guarantees for the judicial security of individuals. Since the judiciary, like other government agencies, is trusted by the public, through open public hearings, its performance is monitored directly by the public and by public opinion, and it is protected from bias and, through oversight, the judicial security of individuals is adequately maintained and guaranteed.

Therefore, the openness of the hearing will allow the public to be monitored and the administration of justice a fair way forward.

The need for open trials in Article 10 of the Universal Declaration of Human Rights states: "Everyone has the right to a fair and public hearing by an independent and impartial tribunal for the determination of his rights and obligations or of criminal charges." The first paragraph of Article 14 of the International Covenant on Civil and Political Rights (1966) also includes the principle of openness of trials. Although this principle is found in the human rights documents and the Constitution of the Islamic Republic of Iran (Article 165), it is not practiced in practice and is generally interpretable as excluding the justices of the judiciary and having no motive for public presence or lack of awareness of the issue. The implementation of this principle has become important. The secrecy of the trials may prevent undue disclosure of the judicial system and lead to the perversion of justice.

Governments in the security-oriented approach and in the fight against a generation of crimes, particularly transnational organized crime and transnational crime, argue that safeguarding the security of the country from fair principles and hold arbitrary hearings in secret.

Article 165 of the Constitution of the Islamic Republic of Iran states: Public trials shall be conducted and the presence of persons shall be permitted unless it is contrary to the public's discretion or public order to determine whether the court is public. Article 168 of the constitution states: The investigation of political and press crimes is open and is attended by juries in the courts of justice. At present, according to the definition of political crime in the Political Crime Act of 1395, there are some exceptions to the political crime and consequently there is a definition in the new Islamic Penal Code as a punishment in the chapter. Thus, for the sake of rhetoric, Vatican was not politically motivated for security reasons, which was argued to be a public commentary on the constitution referred to in the constitution.

\section{Principal 4: Immediate Receipts}

The principle of due process is set out in the reasonable time limit of Article 14 of the Covenant on Civil and Political Rights, and it stipulates that "... any person shall, without prejudice, be entitled to the full guarantees of full enjoyment of the... "Therefore, compliance with international standards is considered. Criminal proceedings in its particular sense involve criminal court proceedings, and the main task of the trial begins from the beginning of the hearing and its role in this in terms of its effect, the defendant's final writing is more prominent. A hearing means a hearing at which you will adjudicate or hear. The fact is that the purpose of a fair trial is to ensure that the defendants are not charged for a long time until the charges are established. In other words, to file a lawsuit at the appropriate time, which is not too fast, urgent, nor too long. As in a conventional trial, the ruling prevails without undue delay. Avoiding speedy and non-observance of defendants' rights of defense is also expedient, with immediate and out-ofcourt criminal proceedings not being followed by ordinary due process. Persons charged with criminal offenses must have adequate opportunity and facilities to provide their defense against the allegations made against them. Therefore, investigating a charge in a reasonable time is one of the most important criteria in a fair trial.

Compliance with Reasonable Time Limits, for the first time in Iran, has been enshrined in the Code of Fair Procedure as one of the principles of fair trial. In such a way as to violate the fundamental principles of the law, such as the principle of innocence, the right to be accused as soon as possible, the enjoyment of defense rights, such as the right to a lawyer, the enjoyment of a forensic expert ..., the guarantee of nullity, Speedy, fast-paced data can be approached in a fast-paced, inquisitive manner.

In some cases, and in particular in security-related cases, such as riots and corruption on earth, real-time and It goes out of its way, and in all these cases all the efforts of the courts and the authorities of the criminal justice system are focused on speedy investigation and determination of the defendant's duty to respond to public opinion and the minds of the offender. The court, instead of focusing on fair and equitable proceedings. In a security-centric approach, there is a tendency to maintain security. This is an urgent and out-of-date consideration, contrary to the provisions of Article 3 of the Criminal Procedure Code of 2013 and international documents, including Article 11 of the Universal Declaration of Human Rights and Article 14 of the Covenant on Civil and Political Rights, which it ratified on 7 May. 1354, its provisions are necessary for the Iranian judicial system, and any urgent proceedings without regard to the guarantees of due process and to the exclusion of public opinion are contrary to the provisions of this article. 
Principal 5: Restriction of the right to defend

The focus of fair and equitable proceedings, based on human rights standards to which Iran has acceded, as well as domestic law, such as the constitution, considers the use of lawyer services as the primary rights of the parties.

The right to have a lawyer under the Covenant on Civil, Political Rights, and Article 14 of the Covenant, is explicitly stated: "Everyone has the right to stand trial and to defend himself, in person or by his own lawyer, in the absence of a lawyer. "The right to have a lawyer shall be informed that, in cases where the law requires, the court will appoint a lawyer for him or her.

The right to have a lawyer appears to have a high degree of enforcement under the Covenant on Civil and Political Rights and is explicitly provided for in Article 14 of the Covenant.

Note to Amendment 48 of the Code of Criminal Procedure, passed in 2013, restricts the right to choose lawyers from among jurists approved by the judiciary. "In crimes against national or foreign security and in organized crime punishable under Article 302 of this Code. At the preliminary investigation stage, the litigants choose their attorneys or attorneys from among the official lawyers of the judiciary who are approved by the judiciary. The names of the lawyers are announced by the head of the judiciary. "

In criminal offenses and corruption on the ground, as they are considered crimes against security, in accordance with Article 48 of the Code of Criminal Procedure, the election of a lawyer must necessarily be from a lawyer approved by the judiciary.

By enforcing a note and limiting the right to free access to a lawyer, which is the most important form of access to justice. Practically, it results in corrupt practices, including the consequences of the unity and focus of the judicial authorities involved in the cases under consideration, namely the judge, the narrator, the mediator and the lawyer, and the undermining of the right to self-defense and the violation of the principle of proportionality, impartiality in defense and independence. The power of attorney is that of sovereignty. The security of the public has also been hampered by the choice of a trusted lawyer, and the mistrust of the defendant and his relatives to lawyers who have a clear relationship with the plaintiff and the bailiffs. It should be noted that without such limitation, in accordance with Article 100 of the aforementioned Law, access to information classified by the claimants may be prevented.

In criticism of this note, Dr. Najafi Tavana, the head of the Bar Association, told the board of directors of the Bar Association: "The principle is unjustified and the lawyer has the right to attorney under law. Selective selection of lawyers from the legal community cannot be due to lack of standard and meaning and legal and religious reference. In principle, such a jurisdiction is unjustified and, when not qualified, is legally entitled to attorney. The crimes in Nusra, this article, and the organized crime referred to in Article 302, Criminal Court One, constitute a significant proportion of the country's criminal offenses that require the use of qualified and experienced defense lawyers. Is it not a right to deprive a client of a specialist lawyer and deprive a lawyer of access to these cases? "

Another human rights violation is against the principle of equality of arms because of this notion of the judiciary and the defense of a subsidiary, a judicial system, and a position that the appellant is also appointed to. The judiciary is a community. The union of these three pillars in one system destroys the principle of equality of arms and undermines the rights of the client or the public. If the purpose of the proceedings is to establish judicial justice, one party should not be actively prosecuted, and the other party should not be prosecuted.

Therefore, this note has introduced an inappropriate restriction on the right to self-defense, one of which is the right to choose a lawyer, and has considered the judiciary inaccurate in criminal offenses against domestic and foreign security, including in Baghi and on earth.

Given that, in principle, the current practice of human rights violators is the issuance of resolutions by the United Nations Commission on Human Rights and to a higher degree of political, economic, economic and other sanctions, which in addition to its negative consequences, Dismantling the international image of the country in the minds of the International Assembly and leading to global rejection. Domestic law should therefore not be detached from human rights standards in internationally accepted documents.

From the topics discussed in this study, it can be concluded that

1- The importance of the right to life and its prohibition is recognized in Islam and in international human rights instruments.

2. By examining the provisions of international documents, despite the anticipation of the death penalty for the most important crimes, the position of the documents towards the abolition of the death penalty is in the list of countries' penal system. The important point is that, according to the Human Rights Committee's interpretation, the death penalty should not be used in relation to property, economic crimes and crimes that do not entail coercion.

3. In the Islamic Republic of Iran, the death penalty was envisaged in nine cases prior to the adoption of the Islamic 
Penal Code of 1992, but with the passage of that law, the death penalty for aggravated assault and aggravated assault was added.

4. With these interpretations, the legislator, despite the policy of decriminalization, provided for in the Fifth Amendment to the International Documentation Schedule to Abolish the Death Penalty from the List of States, with new offenses in addition to the imposition of severe capital punishment, The list of security offenses that have been deviated from some substantive and substantive principles, the most important of which have been avoided in criminal cases, is the principle of legality of penalties; the legislator's position is not clear for the reasons stated; Being, like imposing severe punishment on people who provoke subversion Committing or colluding to commit a crime solely by agreement, including the principle of proportionality of penalties, such as the death penalty for assisting in the on-the-ground corruption, and the execution of persons opposed to the armed uprising system, as a rebuttal if required by jurisprudential sources. In addition, They have been mentioned to the substantive objections and challenges to the form, as opposed to the international instruments adopted by the legislature, there are challenges that include urgent and out-of-date processing of the offenses, both referred to in the Covenant on Civil and Political Rights. In Islamic Penal Code and Criminal Procedure Law and the Right to Defend, which, contrary to Article 14 of the Covenant on Civil Rights, is expressly limited to the choice of security offenses, including rebellion and corruption on earth, under Article 48 of the Code of Criminal Procedure of 2013 Lawyer is one of the lawyers approved by the judiciary who complies with international human rights standards It has wings.

\section{BIBLIOGRAPHIC REFERENCES}

Aghababaei, Hussein. (2018). Legal Jurisprudence Investigation of Subversion.

Hossein Aghaeinia. (2018). Crime Against Individuals (Spiritual Personality) Mizan Publishing House, Tehran First Edition

Mahdavi Pour, Shahrani Kurdi, Azam, Najmeh. (2017). Restrictions on Fair Trials in the Light of Security Criminology, Law Journal of Justice, Eighty-first Year, Spring 96,

Mir Dzapoor, Moshizi. (2019). Guarantee of Non-Compliance with Reasonable Deadline, Quarterly Journal of Excellence in Law, 4th year, June 16 and July 9

Mir Mohammad Sadeghi Hossein. (2018). Article deviation from the principles of criminal law, Strategic Magazine, No. 76,

Omidi, Jalil. (2017). "Principles of Publicity in Criminal Procedure”, Quarterly Journal of Humanities, Comparative Law Research, No. 58,

Shams, Abdullah. (2008). Civil Procedure, Second Edition of Drak Publishing, Chaharmah Print, Fall 82

Shams, Abdullah (2007). Civil Procedure, Volume II of Drak Publications, Chaharmah Print, Fall 82

Shariati Bagheri (2010). Mohammad Javad. International Criminal Court Documents 